Article

\title{
Stressful Conditions Affect Seed Quality in Glyphosate Resistant Conyza bonariensis (L.)
}

\author{
Gabriel da Silva Amaral ${ }^{1}$, Ricardo Alcántara-de la Cruz ${ }^{1, * 0}$, Flávia Regina da Costa ${ }^{2}$, \\ Cileide Maria Medeiros Coelho ${ }^{2}$, Rafael De Prado ${ }^{3}$ (D) and Leonardo Bianco de Carvalho ${ }^{2,4}$ (D) \\ 1 Departamento de Química, Universidade Federal de São Carlos, São Carlos 13565-905, Brazil; \\ amara191gabriel@gmail.com \\ 2 Centro de Ciências Agroveterinárias, Universidade do Estado de Santa Catarina, Lages 88520-000, Brazil; \\ flav_regina@hotmail.com (F.R.d.C.); cileide.souza@udesc.br (C.M.M.C.); \\ leonardo.carvalho@unesp.br (L.B.d.C.) \\ 3 Department of Agricultural Chemistry and Edaphology, University of Córdoba, 14071 Córdoba, Spain; \\ qe1pramr@uco.es \\ 4 School of Agricultural and Veterinary Sciences, São Paulo State University, Jaboticabal 14884-900, Brazil \\ * Correspondence: ricardo.cruz@ufscar.br; Tel.: +16-3351-8093
}

Received: 15 September 2020; Accepted: 31 October 2020; Published: 4 November 2020

\begin{abstract}
Conyza bonariensis (L.) Cronquist is one of the main glyphosate-resistant weeds in no-till fields in Brazil. Here, the seed quality of glyphosate-resistant (R) and -susceptible (S) C. bonariensis biotypes, collected from different sites, was evaluated under stressful conditions by different seed tests. Glyphosate resistance was confirmed by dose-response and shikimate accumulation assays. The resistance factors were 6.9 (R1/S1), 4.5 (R2/S2), and 5.8 (R3/S3). Biotypes S1, S2, and S3 accumulated 2.7, 2.4, and 2.8 times more shikimic acid than biotypes R1, R2, and R3, respectively. Stress-free seed viability and germination potential ranged from $39 \%$ to $57 \%$ and from $37 \%$ to $57 \%$, respectively, with no difference between $\mathrm{R}$ and $\mathrm{S}$ biotypes within each collection site. Seed incubation at $8{ }^{\circ} \mathrm{C}$ over 7 days (cold test) promoted greater germination in S biotypes (54\% to $79 \%$ ) compared to R ones ( $28 \%$ to $39 \%$ ). In the accelerated aging tests (incubation at $42{ }^{\circ} \mathrm{C}$ over 48 hours), the germination decreased in both S (11\% to $27 \%)$ and $\mathrm{R}(6 \%$ to $16 \%)$ biotypes. In the high-temperature stress tests, there were no differences in germination within biotypes at 35 and $45^{\circ} \mathrm{C}$; however, at $60{ }^{\circ} \mathrm{C}$, the germination of the S1, R1, S2, R2, S3, and R3 biotypes was reduced by approximately 51\%, 54\%, 63\%, 59\%, 40\%, and $30 \%$, respectively. Under non-stressful conditions, germination potential and seed viability were similar in R and S biotypes; however, under cold or heat stress conditions, R biotypes reduced their germination rates, revealing that glyphosate resistance causes a fitness penalty in $C$. bonariensis at the seed level. However, because seed viability was not determined after experiments, it cannot be stated that such reduction in germination was due to the death or only a dormant phase of the seeds.
\end{abstract}

Keywords: fitness penalty; germination rate; high-temperature stress; seed viability

\section{Introduction}

Weeds of the Conyza genus are very prolific species that produce small seeds that are easily dragged by the wind because their pappus reduces the speed of settlement [1], contributing to the dispersion of seeds to adjacent and long-distance areas before they fall to the ground [2]. Conyza species are native to South and North America, but today are widespread in a wide variety of agronomic crop systems worldwide [3,4]. These weeds self-pollinate and can produce between 100 and 200 thousand winged seeds, a feature that, combined with their invasive behavior and competitiveness [1,5], makes these species some of the most difficult to manage worldwide [3]. 
Glyphosate (N-(phosphonomethyl)-glycine) is a broad-spectrum herbicide widely used to control weeds in both agricultural and non-agricultural areas [6]. This herbicide is absorbed through foliar tissues and translocated via phloem to meristematic tissues [7], where it inhibits the enzyme 5-enolpyruvyishikimate 3-phosphate synthase (EPSPS). The inhibition of this enzyme in the shikimate pathway prevents the biosynthesis of three essential amino acids (phenylalanine, tyrosine, and tryptophan) [8]. Because the EPSPS inhibition by glyphosate causes shikimic acid accumulation, monitoring of shikimate levels is a widely used parameter to determine glyphosate resistance [9].

Conyza species occur in the Southern, Southeastern, and Midwestern regions of Brazil, making them weeds of agricultural concern [10]. Among the Conyza species, C. bonariensis (L.) Cronquist (hairy fleabane) is the major weed due to its high adaptability to the main production system (no-till) employed in the country, as well as its ability to select for glyphosate resistance [11]. In 2017, it was estimated that glyphosate-resistant Conyza species infested at least 7.7 million ha of soybean alone [12], which corresponded to $\sim 23 \%$ of the area planted with this crop in Brazil and $\sim 10 \%$ of the total planted area in the country [13].

Knowledge of the biology and ecology of weeds plays an important role in planning weed management strategies $[10,14]$. Great efforts have been made to characterize the factors involved in the glyphosate resistance, dispersal, and management of $C$. bonariensis, including growth analysis and bioecological aspects [10]. In considering its seed biology, there is abundant information regarding Conyza's seed germination growing degree days requirements for different sowing dates (autumn, winter, and spring) and agricultural environments [10], as well as its seed viability [11,15], emergence times over a growing season [16], seed longevity [17], and some aspects related to seed quality, such as factors related to seed production, dead seeds, empty seeds, and dormant seeds, among others parameters $[18,19]$. However, studies on how stress conditions (cold or heat) affect the seed quality of glyphosate-resistant $C$. bonariensis-which may contribute to its management by reducing seed persistence, reducing the soil seed bank, and consequently preventing the emergence of weeds at critical times [20]—are scarce.

The objectives of this study were to evaluate the seed quality of glyphosate-resistant and -susceptible C. bonariensis biotypes, collected from different sites of South and Southeast Brazil, subjected to stressful conditions (cold, accelerated aging, and high-temperature) after having characterized the glyphosate resistance by dose-response and shikimate accumulation assays.

\section{Materials and Methods}

\subsection{Seed Collection and Biotypes Isolation}

Seeds of $C$. bonariensis biotypes, based on their biology and ecophysiology traits [21], were collected from several sites in South and Southeast Brazil. The seeds of biotypes with suspected glyphosate resistance were collected from surviving plants after a glyphosate treatment in annual and perennial crop fields. On the other hand, the seeds of susceptible (S) biotypes were collected from plants growing on roadsides near their respective fields where suspected resistant $(R)$ plants occurred. The seed collection was performed during the final flowering stage and seeds were stored in paper bags. The seeds were maintained at room temperature for three months in the laboratory.

The seeds of suspected R-plants were sowed in 10-L plastic pots filled with a mixture of a clay-textured soil and a commercial organic substrate $(3: 1 ; v / v)$. Then, glyphosate (Roundup Original DI, isopropyl amine salt, $360 \mathrm{~g} \mathrm{~L}^{-1}$ of acid equivalent (ae), Monsanto do Brasil Ltda.) was applied to four-leaf plants at $720 \mathrm{~g}$ a $\mathrm{ha}^{-1}$ to eliminate susceptible individuals from the field-collected seeds. Surviving plants were grown separately under greenhouse conditions, and the seeds produced were collected, stored in paper bags, and labelled according to their specific collection site. These purified seeds were used for further experiments. Six biotypes (S1, R1, S2, R2, S3, and R3) that originated from three sites (A, B, and C) were used in this study (Table 1). 
Table 1. Geographical locations of the Brazilian sites of seed collection of Conyza bonariensis biotypes.

\begin{tabular}{cccc}
\hline Site & Municipality/State & Biotype & Coordinates \\
\hline \multirow{2}{*}{ A } & \multirow{2}{*}{ Passo Fundo, Rio Grande do Sul } & S1 & $-28^{\circ} 20^{\prime} 03^{\prime \prime}$ S and $-52^{\circ} 17^{\prime} 00^{\prime \prime} \mathrm{W}$ \\
& \multirow{2}{*}{ B } & R1 & $-28^{\circ} 19^{\prime} 56^{\prime \prime}$ S and $-52^{\circ} 17^{\prime} 10^{\prime \prime} \mathrm{W}$ \\
\hline \multirow{2}{*}{ Palmeira, Paraná } & S2 & $-25^{\circ} 24^{\prime} 26^{\prime \prime}$ S and $-50^{\circ} 00^{\prime} 13^{\prime \prime} \mathrm{W}$ \\
& & $\mathrm{R} 2$ & $-25^{\circ} 24^{\prime} 32^{\prime \prime} \mathrm{S}$ and $-50^{\circ} 00^{\prime} 11^{\prime \prime} \mathrm{W}$ \\
\hline \multirow{2}{*}{$\mathrm{C}$} & \multirow{2}{*}{ Matão, São Paulo } & S3 & $-21^{\circ} 36^{\prime} 05^{\prime \prime} \mathrm{S}$ and $-48^{\circ} 25^{\prime} 56^{\prime \prime} \mathrm{W}$ \\
& & $\mathrm{R} 3$ & $-21^{\circ} 36^{\prime} 18^{\prime \prime} \mathrm{S}$ and $-48^{\circ} 26^{\prime} 10^{\prime \prime} \mathrm{W}$ \\
\hline
\end{tabular}

Seeds of $\mathrm{R}$ and $\mathrm{S}$ C. bonariensis biotypes were sowed in 500-mL plastic pots ( $11 \mathrm{~cm}$ diameter) filled with a mixture of a clay-textured soil and a commercial organic substrate $(3: 1 ; v / v)$. Plants (one plant per pot) were grown in a growth chamber under $25^{\circ} \mathrm{C}$ temperature, 14 -h photoperiod, and $60 \%$ relative humidity. Plants at the rosette stage were used for the herbicide treatments.

\subsection{Dose-Response Assay}

$\mathrm{R}$ and S C. bonariensis biotypes from each collection site were contrasted by dose-response assays. Glyphosate was applied on plants at the doses of 0, 22.5, 45, 90, 180, 360, 720, 1440, 2880, and $5760 \mathrm{~g}$ ae ha ${ }^{-1}$. A backpack sprayer pressurized with $\mathrm{CO}_{2}$ equipped with two fat flan nozzles XR 110.02 VS was used for herbicide application, delivering a $200 \mathrm{~L} \mathrm{ha}^{-1}$ spray volume. Ten plants per herbicide dose were treated, and 30 days after application, plants were cut close to the soil. The shoots were stored in paper bags and then dried in a forced air oven for five days at $60^{\circ} \mathrm{C}$. After that, dry mass was measured using a semi-analytical balance $( \pm 0.01 \mathrm{~g})$. Data were expressed as a percentage in relation to the untreated control $\left(0 \mathrm{~g} \mathrm{ha}^{-1}\right)$.

\subsection{Shikimic Acid Assay}

The quantification of shikimic acid accumulation after herbicide application was used to confirm the glyphosate resistance in the R biotypes, according to the methods employed by Carvalho et al. [22]. Glyphosate was applied to ten $C$. bonariensis plants at 0 and $720 \mathrm{~g} \mathrm{ae} \mathrm{ha}^{-1}$. A backpack sprayer pressurized with $\mathrm{CO}_{2}$ and equipped with two fat flan nozzles 110.02 vs. was used for herbicide application, delivering a $200 \mathrm{~L} \mathrm{ha}^{-1}$ spray volume. Seven days after herbicide application, green leaves were gathered, stored in paper bags, and then dried in a forced air convection oven for seven days at $60{ }^{\circ} \mathrm{C}$. Then, dried material was ground with a Willey mill grinder (20-mesh), stored in plastic bags, and frozen at $-20{ }^{\circ} \mathrm{C}$ until analyses. The content of shikimic acid was determined with a high-performance liquid chromatography and mass spectrometry system. Data are expressed as the accumulation of shikimic acid after glyphosate application determined by the difference in the concentration of shikimic acid between treated and untreated plants.

\subsection{Seed Viability by Tetrazolium Test}

Tests with C. bonariensis seeds were performed according to the methods used by Costa et al. [23]. The seeds used in these experiments were taken at random to avoid biases regarding the seed quality found in the field. In the tetrazolium test, embryos were extracted after seeds were soaked in water for $24 \mathrm{~h}$. After removal, embryos were submerged into a $0.6 \%$ tetrazolium solution overnight at $30{ }^{\circ} \mathrm{C}$. Embryos were observed under a stereo microscope (40× magnification) regarding the presence (viable embryos) or absence (unviable embryos) of a red/rose colored area. Data are expressed as a percentage of viable embryos.

\subsection{Seed Stress Tests}

For the germination potential, cold, and accelerated aging tests, seeds were placed on a sheet of blotting paper in plastic boxes $(11 \times 11 \mathrm{~cm})$, moistened with distilled water at a volume equivalent to 
2.5 times the weight of the dry paper, and then the plastic boxes were sealed with a plastic film. In the high-temperature stress tests, seeds were firstly put inside aluminum capsules and incubated at 35 , 45 , and $60^{\circ} \mathrm{C}$ for $48 \mathrm{~h}$, before placing them in the boxes. Cold test seeds were incubated for 7 days at $8{ }^{\circ} \mathrm{C}$, while the accelerated aging test seeds were incubated at $42^{\circ} \mathrm{C}$ for only $48 \mathrm{~h}$. After applying the different procedures for each test, the boxes were incubated at $25^{\circ} \mathrm{C}$ and a 12 -h light photoperiod under $35 \mu \mathrm{mol} \mathrm{m}{ }^{-2} \mathrm{~s}^{-1}$ flux rate delivered by cool white fluorescent tubes. Germination of seed was evaluated 4 days after incubation.

All experiments were performed in a completely random design with four replicates (with each replicate consisting of one box with fifty seeds) per biotype, and experiments were repeated twice. Data are expressed as a percentage of viable embryos in the tetrazolium test and as a percentage of normal germinated seeds.

\subsection{Statistical Analysis}

Dose-response data were fitted to a nonlinear (log-logistic) regression model: $Y=\min +\{(\max$ $-\mathrm{min}) /\left[1+\left(\mathrm{x} / \mathrm{EC}_{50}\right)\right.$ Hillslope] $\}$ [24], where $\mathrm{Y}$ is the shoot dry mass expressed as a percentage of the untreated control, min and max are the coefficients corresponding to the lower and upper asymptotes, Hillslope is the slope of the line, $\mathrm{EC}_{50}$ is the herbicide dose at the point of inflection halfway between the upper and lower asymptotes (i.e., the $\mathrm{GR}_{50}$ ), and $\mathrm{x}$ is the herbicide dose. The dose required to reduce shoot dry mass by $50 \%\left(\mathrm{GR}_{50}\right)$ was expressed by the $\mathrm{EC}_{50}$ adjusted to a decimal place, and the dose required to reduce shoot dry mass by $80 \%\left(\mathrm{GR}_{80}\right)$ was estimated by using the adjusted equation for both $\mathrm{R}$ and $\mathrm{S}$ biotypes. The resistance factor $(\mathrm{RF})$ was calculated for $\mathrm{GR}_{50}$ and $\mathrm{GR}_{80}$, relating glyphosate-S and $-R$ biotypes within the same collection site, as follows: $R_{50}=G_{50}(R) / G R_{50}(S)$ and $\mathrm{RF}_{80}=\mathrm{GR}_{80}(\mathrm{R}) / \mathrm{GR}_{80}(\mathrm{~S})$.

Because local environmental conditions affect seed quality [25], the R and S C. bonariensis biotypes were analyzed only within collection sites. For the shikimic acid assay, tetrazolium test, germination potential test, cold test, and accelerated aging test, data were analyzed by $t$ test, while for the high-temperature stress test, data were firstly analyzed by ANOVA in a factorial design (two biotypes $\times$ three temperatures), comparing $S$ and $R$ biotypes originating from the same site. Values of $p>0.05$ denoted significant differences and the means were compared by the Tukey test at $95 \%$ probability.

\section{Results}

\subsection{Dose-Response Assay}

For each seed collection site, glyphosate reduced the shoot dry mass of the $\mathrm{S} C$. bonariensis biotypes at lower doses than the $\mathrm{R}$ biotypes at 30 days after herbicide application (Figure 1). The $\mathrm{GR}_{50}$ values were 91 and 628 (S1 and R1), 79 and 350 (S2 and R2), and 88 and $511 \mathrm{~g} \mathrm{ae} \mathrm{ha}^{-1}$ (S3 and R3), respectively.

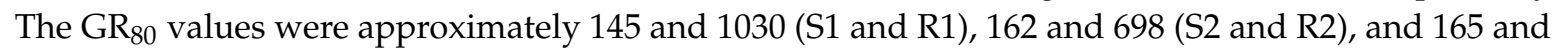
$745 \mathrm{~g}$ ae ha ${ }^{-1}$ (S3 and R3), respectively. The resistance factors were found to be 6.9 and 7.1 (R1/S1), 4.5 and $4.3(\mathrm{R} 2 / \mathrm{S} 2)$, and 5.8 and $4.6(\mathrm{R} 3 / \mathrm{S} 3)$, considering the $\mathrm{RF}_{50}$ and $\mathrm{RF}_{80}$ values, respectively (Table 2).

\subsection{Shikimic Acid Assay}

The S C. bonariensis biotypes accumulated more shikimic acid than the R biotypes within each seed collection site. The accumulation of shikimic acid was approximately 18,132 and $6808 \mu \mathrm{g} \mathrm{g}^{-1} \mathrm{dry}$

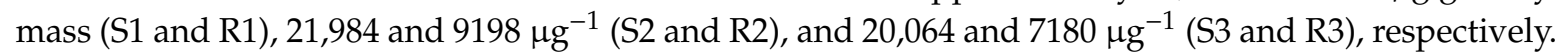
Thus, biotypes S1, S2, and S3 accumulated 2.7, 2.4, and 2.8 times more shikimic acid than biotypes R1, R2, and R3, respectively (Figure 2). 

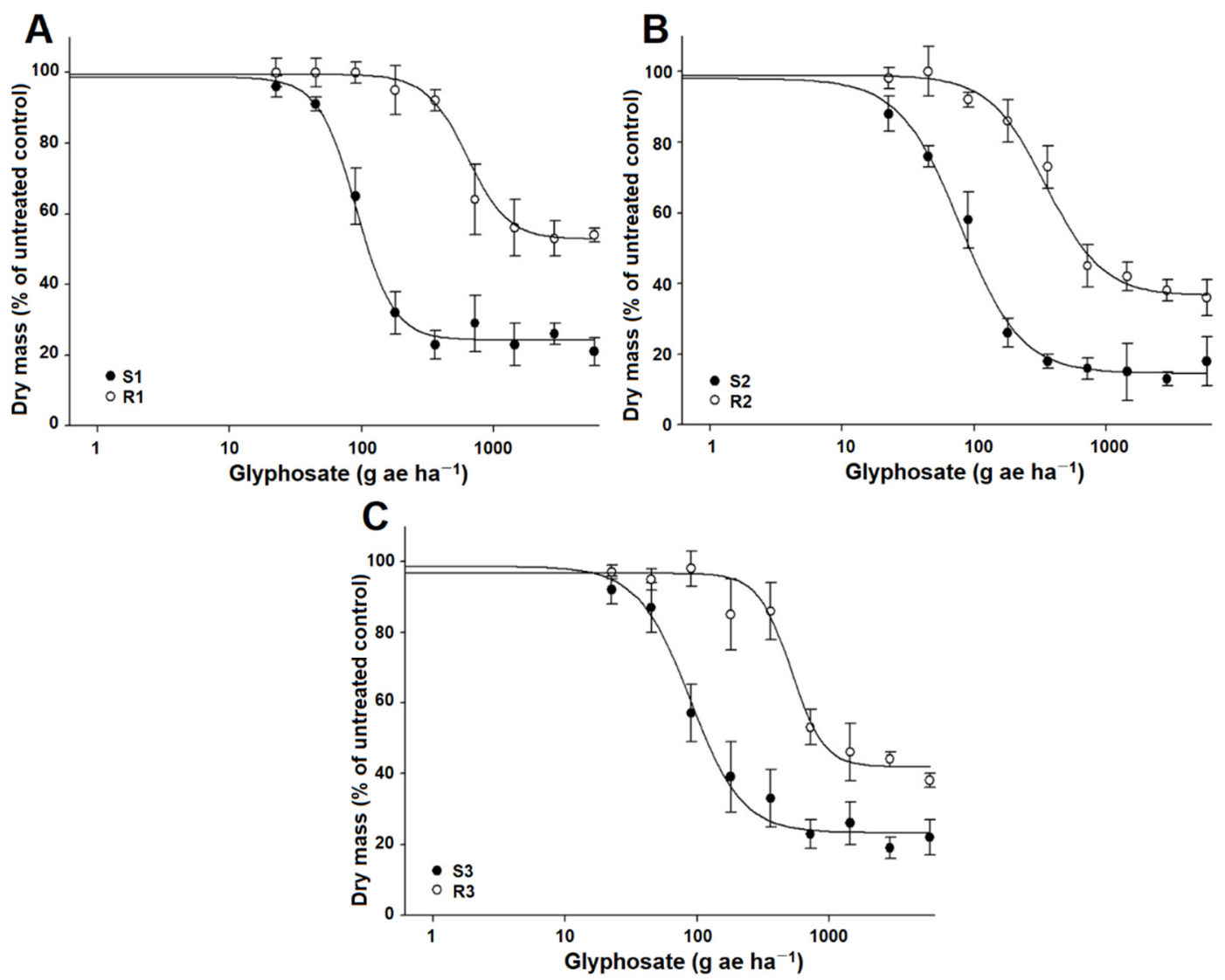

Figure 1. Relation between shoot dry mass and glyphosate dose in dose-response assays for glyphosate-susceptible (S) and -resistant (R) Conyza bonariensis biotypes at 30 days after herbicide application. Seeds were collected in Passo Fundo-RS (A), Palmeira-PR (B), and Matão-SP (C), Brazil. Vertical lines represent the standard error of means $(n=10)$.

Table 2. Equation parameters, coefficient of determination $\left(R^{2}\right)$, significance of regression ( $p$-value), and glyphosate doses required to reduce shoot dry mass by $50 \%\left(\mathrm{GR}_{50}\right)$ and $80 \%\left(\mathrm{GR}_{80}\right)$, as well the respective resistance factor $\left(\mathrm{RF}_{50}\right.$ and $\left.\mathrm{RF}_{80}\right)$, of glyphosate-susceptible $(\mathrm{S})$ and -resistant $(\mathrm{R})$ Conyza bonariensis biotypes collected from three seed collection sites in Brazil.

\begin{tabular}{|c|c|c|c|c|c|c|c|c|c|c|}
\hline \multirow{2}{*}{\multicolumn{2}{|c|}{$\begin{array}{l}\text { Site }^{/ 1} \\
\text { Biotype }\end{array}$}} & \multicolumn{5}{|c|}{ Parameters $^{/ 2}$} & \multirow{2}{*}{$\mathrm{GR}_{50}$} & \multirow{2}{*}{$\mathrm{RF}_{50}$} & \multirow{2}{*}{$\mathrm{GR}_{80}$} & \multirow{2}{*}{$\mathrm{RF}_{80}$} \\
\hline & & $\min$ & $\max$ & Hillslope & $R^{2}$ & $p$-Value & & & & \\
\hline \multirow[b]{2}{*}{ A } & S1 & 24.3 & 98.7 & 3.0 & 0.9773 & $<0.001$ & 90.6 & \multirow{2}{*}{6.9} & 145.1 & \multirow{2}{*}{7.1} \\
\hline & R1 & 52.8 & 99.4 & 2.8 & 0.9765 & $<0.001$ & 628.0 & & 1030.1 & \\
\hline \multirow{2}{*}{ B } & S2 & 14.6 & 97.9 & 1.9 & 0.9756 & $<0.001$ & 78.5 & \multirow{2}{*}{4.5} & 161.8 & \multirow{2}{*}{4.3} \\
\hline & $\mathrm{R} 2$ & 36.6 & 98.9 & 2.0 & 0.9747 & $<0.001$ & 349.5 & & 697.9 & \\
\hline \multirow{2}{*}{$\mathrm{C}$} & S3 & 23.3 & 98.6 & 2.2 & 0.9722 & $<0.001$ & 88.1 & \multirow{2}{*}{5.8} & 164.9 & \multirow{2}{*}{4.6} \\
\hline & R3 & 41.9 & 96.7 & 3.6 & 0.9691 & $<0.001$ & 510.8 & & 754.9 & \\
\hline
\end{tabular}

${ }_{11}^{1}$ Seeds were collected in Passo Fundo-RS (A), Palmeira-PR (B), and Matão-SP (C), Brazil. ${ }^{2}$ min and max are the coefficients corresponding to the lower and upper asymptotes, $\mathrm{GR}_{50}$ is the herbicide dose at the point of inflection halfway between the upper and lower asymptotes, and Hillslope is the slope of the line.

\subsection{Embryo Viability and Germination Potential}

The embryo viability and seed germination potential of C. bonariensis ranged from $37 \%$ up to $57 \%$, with no difference between $\mathrm{S}$ and $\mathrm{R}$ biotypes originating from the same seed collection site. The lowest embryo viability and germination potential, which ranged between $37 \%$ and $43 \%$, were found in seeds from site $\mathrm{A}$. At the $\mathrm{B}$ and $\mathrm{C}$ sites, these parameters ranged from $51 \%$ to $57 \%$ (Figure 3 ). 


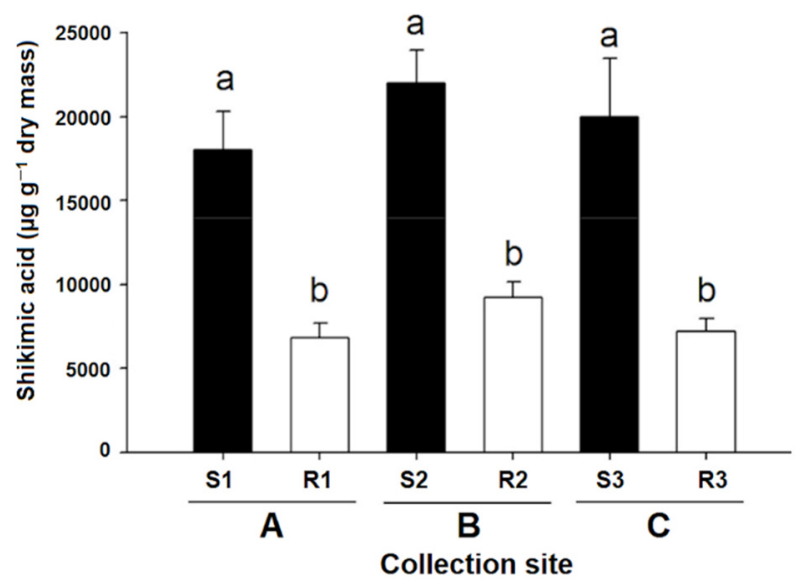

Figure 2. Shikimic acid accumulation in leaf tissues of glyphosate-susceptible (S) and -resistant (R) Conyza bonariensis biotypes at seven days after application of $720 \mathrm{~g}$ ae ha ${ }^{-1}$ glyphosate. Seeds were collected in Passo Fundo-RS (A), Palmeira-PR (B), and Matão-SP (C), Brazil. Vertical lines represent the standard error of means $(n=10)$. Different letters denote statistical differences within a collection site according to the $95 \%$ Tukey test.
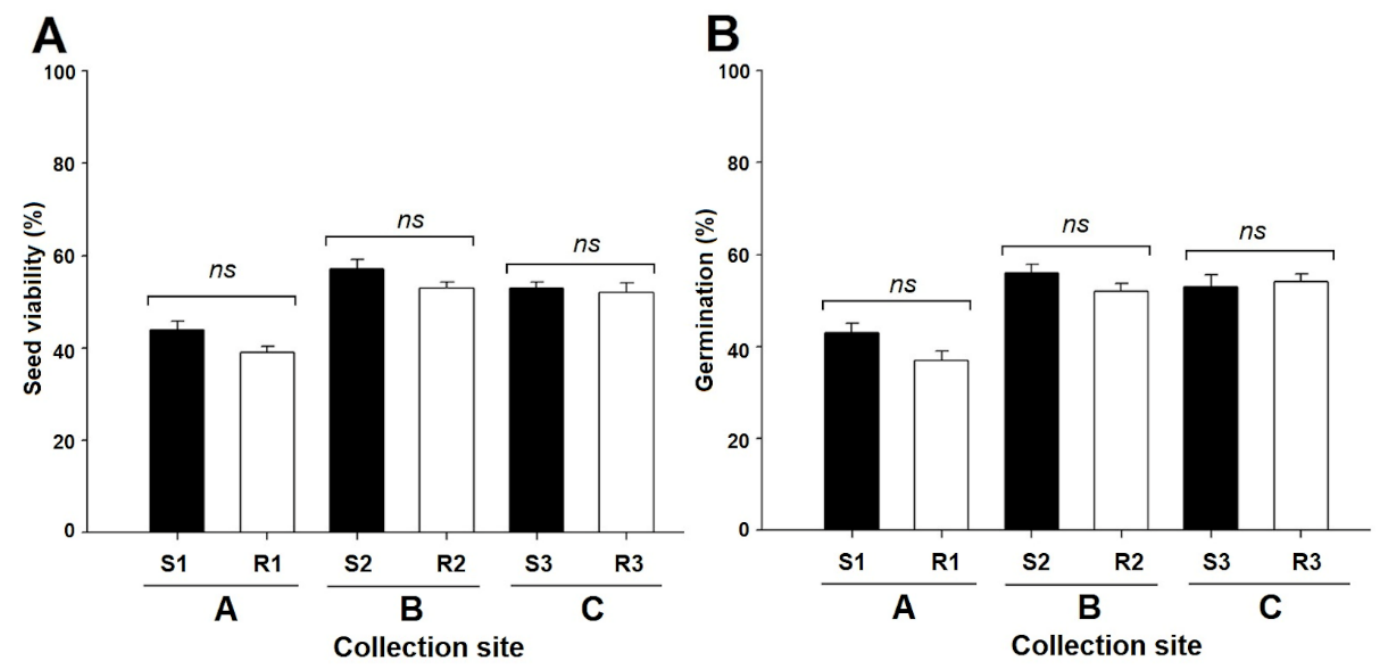

Figure 3. Embryo viability and germination potential in seeds of glyphosate-susceptible (S) and -resistant (R) Conyza bonariensis biotypes. Seeds were collected in Passo Fundo-RS (A), Palmeira-PR (B), and Matão-SP $(\mathbf{C})$, Brazil. Vertical lines represent the standard error of means $(n=4)$ using 50 seeds per replicate. ns: no statistical differences within a collection site according to the $95 \%$ Tukey test.

\subsection{Cold and Accelerated Aging Tests}

The incubation period at $8{ }^{\circ} \mathrm{C}$ a week (cold test) promoted a greater seed germination of $\mathrm{S}$ C. bonariensis biotypes (S1 $=67 \%$; S2 $=79 \%$ and S3 $=54 \%$ ) in relation to their $\mathrm{R}$ counterparts $(\mathrm{R} 1=28 \%$; S2 $=39 \%$ and S3 $=38 \%$ ) (Figure $4 \mathrm{~A}$ ). The germination rates of biotypes S1 and S2 were higher than those observed in the embryo viability and germination potential tests. In the accelerated aging test $\left(48 \mathrm{~h}\right.$ of incubation at $\left.42{ }^{\circ} \mathrm{C}\right)$, the germination rates of the $\mathrm{R}$ biotypes were lower than the $\mathrm{S}$ biotypes, regardless of the collection site. The seed germination was $11 \%$ and $6 \%$ (S1 and R1), $15 \%$ and $7 \%$ (S2 and R2), and 27\% and 16\% (S3 and R3), respectively (Figure 4B).

\subsection{High-Temperature Stress Test}

The S C. bonariensis biotypes showed higher germination rates than the $\mathrm{R}$ biotypes within each temperature regime. The germination of the $\mathrm{S}$ and $\mathrm{R}$ biotypes ranged from $52 \%$ to $63 \%$ and from $29 \%$ 
to $43 \%$, respectively, at 35 and $45^{\circ} \mathrm{C}$. However, there were no differences within biotypes for these temperature regimes. The lowest germination rates were observed at $60^{\circ} \mathrm{C}$ in all biotypes (except for the $\mathrm{R} 3$ biotype, which had a similar germination rate at 35 and $45^{\circ} \mathrm{C}$ ). In this case, the germination of the S1, R1, S2, R2, and S3 biotypes was reduced by approximately $51 \%, 54 \%, 63 \%, 59 \%$, and $40 \%$, respectively, in comparison to the averages observed at 35 and $45^{\circ} \mathrm{C}$ (Figure 5).
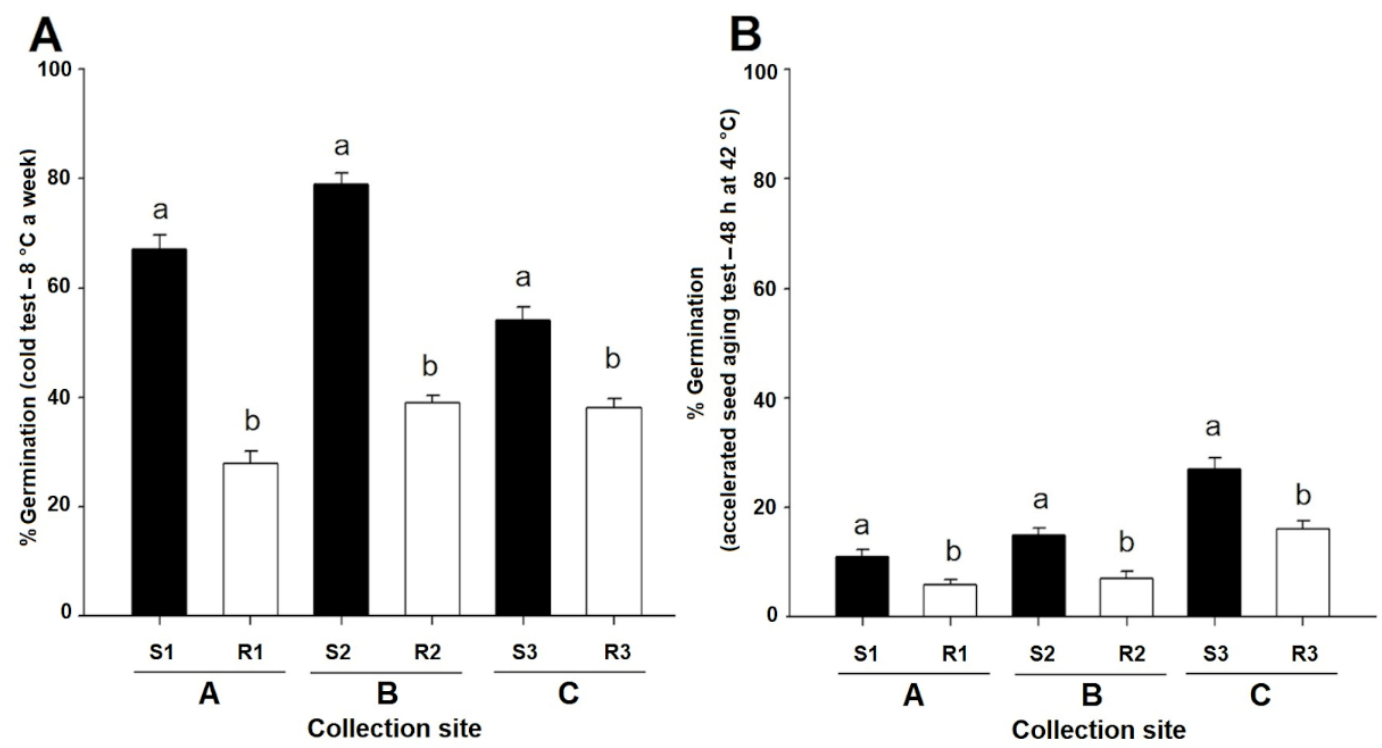

Figure 4. Seed germination under cold (A) and accelerated aging (B) tests in glyphosate-susceptible (S) and -resistant (R) Conyza bonariensis biotypes. Seeds were collected in Passo Fundo-RS (A), Palmeira-PR (B), and Matão-SP $(C)$, Brazil. Vertical lines represent the standard error of means $(n=4)$ using 50 seeds per replicate. Different letters denote statistical differences within a collection site according to the $95 \%$ Tukey test.

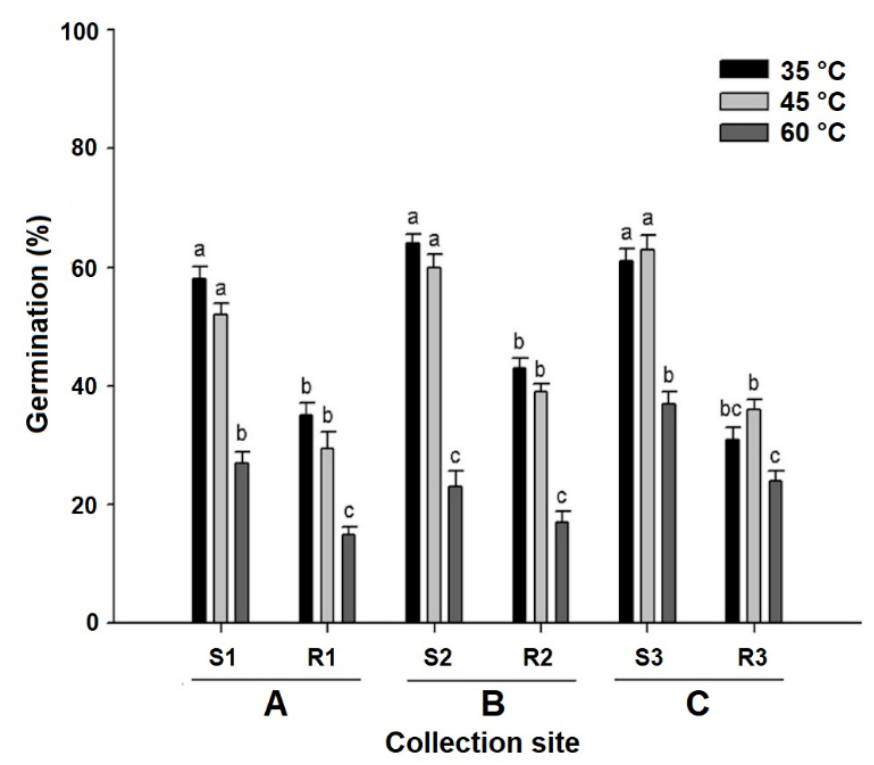

Figure 5. Seed germination under high-temperature stress test for glyphosate-susceptible (S) and -resistant (R) Conyza bonariensis biotypes. Seeds were collected in Passo Fundo-RS (A), Palmeira-PR (B), and Matão-SP $(\mathbf{C})$, Brazil. Vertical lines represent the standard error of means $(n=4)$ using 50 seeds per replicate. Different letters denote statistical differences within a collection site according to the $95 \%$ Tukey test. 


\section{Discussion}

The S C. bonariensis biotypes showed lower $\mathrm{GR}_{50}$ values than the R biotypes. Previous experiments performed with susceptible populations of $C$. bonariensis and C. canadensis have shown $\mathrm{GR}_{50}$ values below $100 \mathrm{~g}$ ae ha $^{-1}[16,26]$, demonstrating that species of the Conyza genus are highly susceptible to glyphosate. In addition, the $\mathrm{GR}_{50}$ values of the $\mathrm{S}$ populations, regardless of the different geographic origins of each biotype, were similar. Piasecki et al. [18] observed a similar phenomenon, with S populations of $C$. bonariensis collected in different regions of southern Brazil showing no differences in their $\mathrm{GR}_{50}$ (also less than $100 \mathrm{~g}$ ae ha ${ }^{-1}$ ). The R biotypes, in turn, presented different $\mathrm{GR}_{50}$ values, revealing different profiles of glyphosate resistance; however, the $\mathrm{GR}_{80}$ values were below the field dose recommended by the manufacturer for this species (960 $\mathrm{g}$ ae ha ${ }^{-1}$ ), except for biotype R1 $\left(\mathrm{GR}_{80}=1.030 \mathrm{~g} \mathrm{ha}^{-1}\right)$. Different glyphosate-resistant Conyza species have shown resistance ratios ranging from 6 to 30 with regard to their $S$ counterparts $[4,27,28]$, depending on the resistance mechanism involved.

Because the EPSPS transforms the shikimate-3-phosphate and phosphoenolpyruvate into EPSP, the inhibition of this enzyme by glyphosate results in the accumulation of shikimic acid in susceptible plants [8]. Both R and S C. bonariensis biotypes accumulated shikimic acid (i.e., glyphosate was equally loaded in the phloem and reached the EPSPS in both biotypes) [29]. Similar results have been found in different studies where both $\mathrm{R}$ and $\mathrm{S}$ biotypes/populations of Conyza species accumulated shikimic acid $[4,30,31]$; however, the accumulation rates of shikimic acid in $R$ plants was always lower than the accumulation observed in $\mathrm{S}$ plants. The low accumulation of shikimic acid between our $\mathrm{R} C$. bonariensis biotypes suggests different resistance mechanism(s), which reduced the amount of glyphosate that reached or interacted with the EPSPS [27].

The viability and germination potential of $C$. bonariensis seeds were similar between biotypes within each collection site. The viability of seeds was low ( $\pm 50 \%$ or less) in relation to other studies that have reported viability rates between $65 \%$ and $80 \%$ in R and S Conyza populations [11,19]. However, there are also cases with lower germination rates [2,23]. This discrepancy in the viability and germination rates may be due to seed longevity; in the particular case of the Conyza species, longevity is short due to the small size of seeds resulting in few stored reserves [32]; therefore, it is normal to observe the deterioration or death of seeds [15]. This suggests that $\mathrm{R}$ and S C. bonariensis seeds of site A were older than those collected at sites B and C. In addition, the geographical origin of the seeds could also have contributed to the differences in germination rates, since evolutionary adaptations to local climate influence the germination of Conyza species [33,34].

In general, Conyza seeds have shallow physiological dormancy [35]; however, in the cold tests (incubation at $8{ }^{\circ} \mathrm{C}$ for $7 \mathrm{~h}$ ), the germination percentage of the S1 and S2 C. bonariensis biotypes was higher than in stress-free germination tests, suggesting that seeds of these biotypes had some type of latency, since this secondary dormancy may be responsible for low germination rates [15]. In relation to the aging accelerated tests (incubation at $42{ }^{\circ} \mathrm{C}$ for $48 \mathrm{~h}$ ), all $\mathrm{C}$. bonariensis biotypes presented low germination percentages $(>30 \%)$, but germination was higher in R biotypes. Aging accelerated tests aim to determine the rate of deterioration processes and potential longevity of seeds [36]. These results suggest that seeds of $\mathrm{R}$ biotypes deteriorate and die faster than seeds of $S$ biotypes at high temperatures. These results are consistent with those observed by Costa et al. [23] in C. bonariensis. At the vegetative level, there is no evidence for fitness cost in glyphosate-resistant Conyza species [5,26,28,37]; however, our results suggest that there may be a seed level fitness penalty in C. bonariensis. Piasecki et al. [18] also observed a reduction in the vigor and germination rate in seeds of glyphosate-resistant Conyza species and, in turn, a significant increase in both empty and dormant seeds. In addition, glyphosate application at the vegetative and reproductive stages impairs the production and viability of glyphosate-resistant C. bonariensis seeds [29].

In the high-temperature stress tests, both $\mathrm{R}$ and S C. bonariensis biotypes reduced their germination potential as the temperature increased. This reduction could be due to the accumulation of abscisic acid in response to exposure to high temperatures, which inhibited the germination and seedling 
establishment [38]. High temperatures, in association with other factors, alter the structures enclosing the embryo, preventing radicle emergence, which causes the death of seeds [39], thus explaining the reduction in the germination rates of $\mathrm{R}$ and $\mathrm{S} C$. bonariensis biotypes collected from different sites. Weed seed thermal death is dependent on the weed species, size of seeds (length $\times$ width $\times$ weight) [40], as well as the temperature regime and the exposure time [41,42]. Amaranthus albus, Echinochloa colona, Portulaca oleracea, Sisymbrium irio, Sonchus oleraceus, and Solanum nigrum presented $100 \%$ of seed mortality when exposed to $50^{\circ} \mathrm{C}$; however, the exposure time required ranged from $4 \mathrm{~h}$ up to $113 \mathrm{~h}$, depending on the weed species [41,42]. In another study, the exposure of A. retroflexus, E. crus-galli, Galinsoga quadriradiata, P. oleracea, Setaria viridis, and S. nigrum to $\pm 60^{\circ} \mathrm{C}$ for $65 \mathrm{~s}$ reduced germination by only $10 \%$; but the exposure of the seeds of these same weed species to $70-80{ }^{\circ} \mathrm{C}$ for $\sim 90 \mathrm{~s}$ caused $100 \%$ seed mortality [40]. Our results suggest that thermal treatments could be an alternative for the control of glyphosate-resistant biotypes of $C$. bonariensis; however, there are no data related to the temperature regimes and exposure times needed to cause seed mortality in Conyza species.

The results revealed that seeds of R C. bonariensis biotypes, subjected to different stressful conditions (cold, heat, and/or accelerated aging), reduced their germination by a greater percentage than that of the $\mathrm{S}$ biotypes. However, the seed viability of $\mathrm{R}$ biotypes was not determined after these experiments; therefore, it cannot be positively stated that such reduction in germination was due to the death of seeds or if the seeds entered a latent phase, although it is widely known that the dormancy of Conyza species is short or non-existent $[15,35]$.

\section{Conclusions}

Glyphosate resistance was corroborated in the C. bonariensis biotypes referred to as R1, R2, and $\mathrm{R} 3$ because they showed high $\mathrm{GR}_{50}$ values and low shikimate accumulation in relation to their $\mathrm{S}$ counterparts. Under stress-free conditions, the germination potential as well as the seed viability were similar between R and S C. bonariensis biotypes; however, under stressful conditions of cold, heat, or accelerated aging, the germination rate of $\mathrm{R}$ biotypes was reduced, regardless of the collection site, showing that glyphosate resistance affects seed quality in C. bonariensis (i.e., there is a fitness penalty at seed level). According to the high-temperature stress tests, thermal treatments could be an alternative for the control of glyphosate-resistant biotypes of $C$. bonariensis.

Author Contributions: Conceptualization: C.M.M.C. and L.B.d.C.; methodology, investigation, and formal analysis: G.d.S.A., R.A.-d.1.C., and F.R.d.C.; resources: L.B.d.C. and R.D.P.; data curation and writing-original draft preparation: G.d.S.A., R.A.-d.I.C., F.R.d.C., C.M.M.C., and L.B.d.C.; visualization and writing-review and editing: R.A.-d.l.C., L.B.d.C., and R.D.P.; supervision, project administration, and funding acquisition: L.B.d.C. and R.D.P. All authors have read and agreed to the published version of the manuscript.

Funding: The authors wish to thank the "Conselho Nacional de Desenvolvimento Cientifico e Tecnológico (CNPq)", "Coordenação de Aperfeiçoamento de Pessoal de Nível Superior (CAPES)", and "Fundação de Amparo à Pesquisa do Estado de São Paulo (FAPESP 2018/15910-6)" for the financial support.

Conflicts of Interest: The authors declare no conflict of interest.

\section{References}

1. Bajwa, A.A.; Aadia, S.; Ali, H.H.; Jabran, K.; Peerzada, A.M.; Chauhan, B.S. Biology and management of two important Conyza weeds: A global review. Environ. Sci. Pollut. Res. 2016, 23, 24694-24710. [CrossRef]

2. Wu, H.; Walker, S.; Rollin, M.J.; Tan, D.K.Y.; Robinson, G.; Werth, J. Germination, persistence and emergence of flaxleaf fleabane (Conyza bonariensis [L.] Cronquist). Weed. Biol. Manag. 2007, 7, 192-199. [CrossRef]

3. Mora, D.A.; Cheimona, N.; Palma-Bautista, C.; Rojano-Delgado, A.M.; Osuna-Ruiz, M.D.; Alcántara-de la Cruz, R.; De Prado, R. Physiological, biochemical and molecular bases of resistance to tribenuron methyl and glyphosate in Conyza canadensis from olive groves in Southern Spain. Plant Physiol. Biochem. 2019, 144, $14-21$. [CrossRef] [PubMed]

4. Tahmasebi, B.K.; Alebrahim, M.T.; Roldán-Gómez, R.A.; Silveira, H.M.; Carvalho, L.B.; Alcántara-de la Cruz, R.; De Prado, R. Effectiveness of alternative herbicides on three Conyza species from Europe with and without glyphosate resistance. Crop Prot. 2018, 112, 350-355. [CrossRef] 
5. Mylonas, P.N.; Giannopolitis, C.N.; Efthimiadis, P.G.; Menexes, G.C.; Eleftherohorinos, I.G. Dose-response and growth rate variation among glyphosate resistant and susceptible Conyza albida and Conyza bonariensis populations. J. Plant Prot. Res. 2019, 59, 32-40.

6. Duke, S.O. The history and current status of glyphosate. Pest Manag. Sci. 2018, 74, 1027-1034. [CrossRef]

7. Preston, C.; Wakelin, A.M. Resistance to glyphosate from altered herbicide translocation patterns. Pest Manag. Sci. 2008, 64, 372-376. [CrossRef] [PubMed]

8. Steinrücken, H.C.; Amrhein, N. The herbicide glyphosate is a potent inhibitor of 5-enolpyruvyl-shikimic acid-3-phosphate synthase. Biochem. Biophys. Res. Commun. 1980, 94, 1207-1212. [CrossRef]

9. Kleinman, Z.; Rubin, B. Non-target-site glyphosate resistance in Conyza bonariensis is based on modified subcellular distribution on the herbicide. Pest Manag. Sci. 2017, 73, 246-253. [CrossRef] [PubMed]

10. Soares, D.O.; Oliveira, W.S.; Uzuele, E.L.; Carvalho, S.J.P.; Lopez-Ovejero, R.F.; Christoffoleti, P.J. Growth and development of Conyza bonariensis based on days or thermal units. Pesqui Agropecu Bras. 2017, 52, 45-53. [CrossRef]

11. Kaspary, T.E.; Lamego, F.P.; Cutti, L.; Aguiar, A.C.M.; Rigon, C.A.G.; Basso, C.J. Growth, phenology, and seed viability between glyphosate-resistant and glyphosate-susceptible hairy fleabane. Bragantia 2017, 76, 92-101. [CrossRef]

12. Adegas, F.S.; Vargas, L.; Gazziero, D.L.P.; Karam, D.; Silva, A.F.; Agostinetto, D. Impacto econômico da resistência de planta daninhas a herbicidas no Brasil. EMBRAPA-Circular Técnica 2017, 132, 1-11.

13. Alcántara-de la Cruz, R.; Oliveira, G.M.; Carvalho, L.B.; Silva, M.F.G.F. Herbicide resistance in Brazil: Status, impacts, and future challenges. In Pests Classification, Management and Practical Approaches, 1st ed.; Kontogiannatos, D., Kourti, A., Ferreira, K.M., Eds.; IntechOpen: Londod, UK, 2020; in press. [CrossRef]

14. Mortensen, D.A.; Bastiaans, L.; Sattin, M. The role of ecology in the development of weed management systems: An outlook. Weed Res. 2000, 40, 49-62. [CrossRef]

15. Agostinetto, A.; Vargas, A.A.M.; Ruchel, Q.; Silva, J.D.G.; Vargas, L. Germination, viability and longevity of horseweed (Conyza spp.) seeds as a function of temperature and evaluation periods. Ciênc Rural. 2018, 48, e20170687. [CrossRef]

16. Shrestha, A.; Hanson, B.D.; Fidelibus, M.W.; Alcorta, M. Growth, phenology, and intraspecific competition between glyphosate-resistant and glyphosate-susceptible horseweeds (Conyza canadensis) in the San Joaquin valley of California. Weed Sci. 2010, 58, 147-153. [CrossRef]

17. Vargas, A.A.M.; Agostinetto, D.; Zandoná, R.R.; Fraga, D.S.; Avila-Neto, R.C. Longevity of horseweed seed bank depending on the burial depth. Planta Daninha 2018, 36, e018172073. [CrossRef]

18. Piasecki, C.; Mazon, A.S.; Agostinetto, D.; Vargas, L. Glyphosate resistance affect the physiological quality of Conyza bonariensis seeds. Planta Daninha 2019, 37, e019213902. [CrossRef]

19. Piasecki, C.; Mazon, A.S.; Monge, A.; Cavalcante, J.A.; Agostinetto, D.; Vargas, L. Glyphosate applied at the early reproductive stage impairs seed production of glyphosate-resistant hairy fleabane. Planta Daninha 2019, 37, e019196815. [CrossRef]

20. Santín-Montanyá, M.I.; Martín-Lammerding, D.; Zambrana, E.; Tenorio, J.L. Management of weed emergence and weed seed bank in response to different tillage, cropping systems and selected soil properties. Soil. Tillage Res. 2016, 161, 38-46. [CrossRef]

21. Lazaroto, C.A.; Fleck, N.G.; Vidal, R.A. Biology and ecophysiology of hairy fleabane (Conyza bonariensis) and horseweed (Conyza canadensis). Cienc. Rural. 2008, 38, 852-860. [CrossRef]

22. Carvalho, L.B.; Duke, S.O.; Alves, P.L.C.A. Physiological responses of Eucalyptus $x$ urograndis to glyphosate are dependent on the genotype. Sci. For. 2018, 46, 177-187. [CrossRef]

23. Costa, F.R.; Stinghen, J.C.; Bortoli, J.R.G.; Coelho, C.M.C.; Carvalho, L.B. Can seed quality of hairy fleabane be reduced due to glyphosate resistance? Rev. Ciênc. Agrovet. 2018, 17, 136-141. [CrossRef]

24. Ritz, C.; Baty, F.; Streibig, J.C.; Gerhard, D. Dose-response analysis using R. PLoS ONE 2015, 10, e0146021. [CrossRef]

25. Delouche, J.C. Environmental effects on seed development and seed quality. HortScience 1980, 15, 13-18.

26. Shrestha, A.; Steinhauer, K.M.; Hanson, B.D.; Jasieniuk, M.; Hembree, K.J.; Wright, S.D. Growth and development of fall- and spring-planted populations of Conyza canadensis and C. bonariensis. Int. J. Pest Manag. 2016, 62, 300-307. [CrossRef]

27. González-Torralva, F.; Cruz-Hipolito, H.; Bastida, F.; Mülleder, N.; Smeda, R.J.; De Prado, R. Differential susceptibility o glyphosate among the Conyza weed species in Spain. J. Agric. Food Chem. 2010, 58, 4361-4366. [CrossRef] 
28. Travlos, I.S.; Chachalis, D. Relative competitiveness of glyphosate-resistant and glyphosate-susceptible populations of hairy fleabane, Conyza bonariensis. J. Pest Sci. 2013, 86, 345-351. [CrossRef]

29. Piasecki, C.; Carvalho, I.R.; Cechin, J.; Goulart, F.A.P.; Maia, L.C.; Agostinetto, D.; Caverzan, A.; Stewart, C.N., Jr.; Vargas, L. Oxidative stress and differential antioxidant enzyme activity in glyphosate-resistant and -sensitive hairy fleabane in response to glyphosate treatment. Bragantia 2019, 78, 379-396. [CrossRef]

30. Okumu, M.N.; Vorster, B.J.; Reinhardt, C.F. Growth-stage and temperature influence glyphosate resistance in Conyza bonariensis (L.) Cronquist. S. Afr. J. Bot. 2019, 121, 248-256. [CrossRef]

31. Vargas, L.; Silva, D.R.O.; Agostinetto, D.; Matallo, M.B.; Santos, F.M.; Almeida, S.D.B.; Chavarria, G.; Silva, D.F.P. Glyphosate influence on the physiological parameters of Conyza bonariensis biotypes. Planta Daninha 2014, 32, 151-159. [CrossRef]

32. Nandula, V.K.; Eubank, T.W.; Poston, D.H.; Koger, C.H.; Reddy, K.N. Factors affecting germination of horseweed (Conyza canadensis). Weed Sci. 2006, 54, 898-902. [CrossRef]

33. Tozzi, E.; Beckie, H.; Weiss, R.; Gonzalez-Andujar, J.L.; Storkey, J.; van Acker, R.C. Seed germination response to temperature for a range of international populations of Conyza canadensis. Weed Res. 2014, 54, 178-185. [CrossRef]

34. Valencia-Gredilla, F.; Supiciche, M.L.; Chantre, G.R.; Recasens, J.; Royo-Esnal, A. Germination behaviour of Conyza bonariensis to constant and alternating temperatures across different populations. Ann. Appl. Biol. 2020, 176, 36-46. [CrossRef]

35. Baskin, C.C.; Baskin, J.M. Seeds: Ecology, Biogeography, and Evolution of Dormancy and Germination, 2nd ed.; Academic Press: San Diego, CA, USA, 2014; 1600p.

36. Marcos Filho, J. Seed vigor testing: An overview of the past, present and future perspective. Sci. Agric. 2015, 72, 363-374. [CrossRef]

37. Beres, Z.T.; Owen, M.D.K.; Snow, A.A. No evidence for early fitness penalty in glyphosate-resistant biotypes of Conyza canadensis: Common garden experiments in the absence of glyphosate. Ecol. Evol. 2019, 9, 13678-13689. [CrossRef]

38. Liu, J.; Hasanuzzaman, M.; Wen, H.; Zhang, J.; Peng, T.; Sun, H.; Zhao, Q. High temperature and drought stress cause abscisic acid and reactive oxygen species accumulation and suppress seed germination growth in rice. Protoplasma 2019, 256, 1217-1227. [CrossRef]

39. Peerzada, A.M.; Chauhan, B.S. Thermal weed control: History, mechanisms, and impacts. In Non-Chemical Weed Control, 1st ed.; Peerzada, A.M., Chauhan, B.S., Eds.; Academic Press: Cambridge, MA, USA, 2018; pp. 9-31.

40. Vidotto, F.; De Palo, F.; Ferrero, A. Effect of short-duration high temperatures on weed seed germination. Ann. Appl. Biol. 2013, 163, 454-465. [CrossRef]

41. Dahlquist, R.M.; Prather, R.M.; Stapleton, J.J. Time and temperature requirements for weed seed thermal death. Weed Sci. 2007, 55, 619-625. [CrossRef]

42. Bauer, M.V.; Marx, C.; Bauer, F.B.; Flury, D.M.; Ripken, T.; Streit, B. Thermal weed control technologies for conservation agriculture-A review. Weed Res. 2020, 60, 241-250. [CrossRef]

Publisher's Note: MDPI stays neutral with regard to jurisdictional claims in published maps and institutional affiliations.

(C) 2020 by the authors. Licensee MDPI, Basel, Switzerland. This article is an open access article distributed under the terms and conditions of the Creative Commons Attribution (CC BY) license (http://creativecommons.org/licenses/by/4.0/). 